\title{
From ethnic group boundary demarcation to deprovincialization: The interplay of immigrant presence and ideological climate
}

International Journal of Comparative Sociology 2018, Vol. 59(5-6) 383-402

(C) The Author(s) 2018 Article reuse guidelines: sagepub.com/journals-permissions DOI: $10.1|77 / 00207| 5218801422$ journals.sagepub.com/home/cos

\section{Eva GT Green}

University of Lausanne, Switzerland

\section{Emilio Paolo Visintin}

University of Lausanne, Switzerland

\section{Oriane Sarrasin}

University of Lausanne, Switzerland

\begin{abstract}
Intergroup contact (i.e. personal encounters with and presence of immigrants) has frequently been related to improved immigration attitudes among the national majority. The impact of ideological climates, in turn, has received scant attention. Drawing on the notion of deprovincialization, we argue that, in proximal geographical contexts, contact with immigrants as well as progressive (vs conservative) ideological climates engender a reappraisal of national ingroup boundaries by attenuating ethnic views of nationhood. As expected, multilevel regression analyses with the Swiss ISSP 2013 data $(N=1019$ Swiss respondents living in 136 districts) revealed that personal encounters with immigrants related to reduced ethnic boundary making. Importantly, on the district level, immigrant presence buffered the impact of conservative ideological climates.
\end{abstract}

\section{Keywords}

Deprovincialization, ethnic boundary making, ideological climate, intergroup contact, International Social Survey Program, multilevel analysis, regional comparisons

\section{Introduction}

When do immigrants become full members of the receiving country? This crucial question, concerning the boundaries between immigrants and the national majority of the receiving country, is omnipresent when defining citizenship and access to nationality. Access to the national ingroup is, 
however, not only a matter of formal regulations. National majority members have differing perceptions about criteria immigrants should fulfill to "qualify" as a member. Some refuse to see naturalized immigrants as "true" citizens. Indeed, when opposition to access to nationality is driven by ethnocentrism, nationhood is conceived in exclusive ethnocultural terms, bound to ancestry, birthplace and religion (Shulman, 2002; Smith, 1991 see also Kunovich, 2009). These ethnic nationhood criteria are hard or impossible to fulfill for most immigrants.

In this article, we examine how intergroup contact and the surrounding ideological climate shape the way members of the national majority construe ingroup boundaries by endorsing or not endorsing ethnic definitions of nationhood. While permeable boundaries of the ingroup denote an inclusive stance toward immigrant outgroups, impermeable boundaries convey an exclusive stance. We draw on the notion of deprovincialization, put forward by intergroup contact theory (Pettigrew, 1997, 2011). Deprovincialization signifies a redefinition of one's group, here the national ingroup, as a more open and inclusive entity. Deprovincialization thus manifests itself as a reduction in ethnic boundary making. From a dynamic view of intergroup relations, deprovincialization is considered an outcome of interactions with outgroup members. We indeed argue that personal encounters with immigrants engender a reappraisal of the national ingroup and its boundaries. Based on prior research (e.g. Wagner et al., 2006; Weber, 2015), we contend that, in proximal geographical contexts, presence of immigrants provides opportunities for contact that foster deprovincialization.

Ideological climates, in turn, entail shared normative forms of thinking about cultural diversity, and societal order more generally, within a given context (e.g. Allport, 1954; Crandall et al., 2002; Green and Staerklé, 2013; Guimond et al., 2014). Ideological climates should play a role too in the degree to which individuals embrace deprovincialization. While there is abundant evidence that individuals' ideological orientations - conservatism, right-wing orientation, anti-egalitarianism underlie attitudes toward immigrants (e.g. Cohrs and Stelzl, 2010; Ford, 2011) and the national ingroup (e.g. Huddy and Khatib, 2007; Sidanius et al., 1997), the impact of the surrounding ideological climate on individuals' attitudes has mostly been neglected. A handful of studies examined how local ideological climates shape individuals' attitudes toward immigrants and ethnic minorities (e.g. Fasel et al., 2013; Sarrasin et al., 2012; Van Assche et al., 2017), but to our knowledge, this is the first study investigating the relationship of ideological climates with deprovincialization. That is, we study the extent to which ideological climates curb or foster ethnic boundary making.

In this research, we attempt to move the discussion forward in three ways. First, we bring together intergroup contact and ethnic boundary making literature by conceptualizing deprovincialization as a reduction in the endorsement of ethnic nationhood. Second, introducing the concept of ideological climate, this article provides a novel empirical contribution to the two bodies of literature by examining how the interplay of immigrant presence and ideological climate shapes deprovincialization. Third, we investigate within-country variation of deprovincialization. In doing so, we go beyond country-level explanations of deprovincialization or ethnic boundary making (Kunovich, 2009; Wright, 2011 see also Bail, 2008; Green, 2009). As there is substantial variation inside countries in the size of immigrant population (e.g. Schlueter and Wagner, 2008; Wagner et al., 2006; Weber, 2015) and the prevailing ideological climate (e.g. Sarrasin et al., 2012; Van Assche et al., 2017), within-country comparisons are much needed.

We study these processes in Switzerland, a highly relevant context for observing support for ethnic boundary making for two reasons. Switzerland's naturalization policies are among the most restrictive in Western Europe, even for second-generation immigrants, involving a long process and demanding conditions that vary depending on the place of residence (see Hainmueller and Hangartner, 2013). Moreover, Swiss citizens directly participate in defining the boundaries of the national ingroup. Due to the political system practicing direct democracy, citizens have opportunities to take a stance on criteria of naturalization through referendums for which results 
vary regionally. After several unsuccessful referendums over the years, in February 2017, a large majority of Swiss citizens $(60.4 \%)$ accepted to facilitate the process of naturalization of thirdgeneration immigrants.

This article is organized as follows. We start by defining ethnic boundary making and discussing its reduction as a form of deprovincialization. Next, drawing on intergroup contact theory, we outline a theoretical rationale for context- and individual-level antecedents of deprovincialization. Then, we test our predictions using a multilevel approach with data from the 2013 International Social Survey Program ISSP National Identity module in Switzerland. Finally, we discuss the implications of our findings.

\section{From ethnic boundaries to deprovincialization}

In current-day multicultural societies, the question of who belongs to the nation is central. Whereas migration, implying moving over borders, can be characterized as a demographic phenomenon, the process of boundary making is political and politicized (Wimmer, 2013; see also Lamont and Molnár, 2002). The boundaries between "us" (the members of the nation) and "them" (the nonmembers) are drawn in multiple ways. Citizenship legislation, by means of institutionalized boundaries, formally establishes who belongs to the nation as well as the process of becoming a member of the nation (Koopmans et al., 2005). Citizenship further determines access to resources, such as voting rights. Citizenship legislation varies across countries from some countries having strict legislation based on jus sanguinis - a "right of blood" with access to nationality determined through parents' citizenship - to others with more lenient legislation, implementing different forms of birthright citizenship, jus soli (e.g. see Brubaker, 1992). Beyond legislation, the contours of a nation as a political community are represented, or imagined, in different ways (Anderson, 2006). Political rhetoric and media depictions of immigration and immigrants convey boundaries of nationhood. Moreover, and the focus of the current research, nationals demarcate boundaries between themselves and non-nationals.

There is substantial variation in the boundaries or criteria employed by nationals to separate themselves from non-nationals or immigrants (Heath et al., 2009; Kunovich, 2009; Wright, 2011). Endorsement of an ethnic view of nationhood - by imposing, for example, ancestry, birthplace or religion as inflexible criteria for citizenship - is a severe way to draw boundaries between the national majority and immigrants. Such ethnic nationhood criteria are hard or impossible to fulfill for most immigrants, and therefore, there is little chance of becoming part of the national ingroup. By way of contrast, the boundaries of the ingroup are more inclusive and permeable when nationhood is conceived to a lesser degree or not at all in ethnic terms. ${ }^{1}$

Over time, boundaries change and are challenged. For example, nationals can contest modifications in citizenship and migration legislation. This is the case when xenophobic movements oppose to the opening of boarders, or in contrast, when social movements make appeals to host refugees. Boundaries also shift: Upon arrival of new immigrant groups, the targets of exclusion change among nationals. In this study, we examine attenuation of ethnic boundary making among national majority members, and conceptualize this phenomenon as deprovincialization. We introduce intergroup contact theory next, and then discuss individual- and context-level antecedents of deprovincialization.

\section{Intergroup encounters and deprovincialization}

Research drawing on intergroup contact theory has repeatedly demonstrated that personal encounters with outgroup members (ranging from superficial interactions in everyday life to friendships) 
reduce prejudice (Allport, 1954; Hewstone and Swart, 2011; Pettigrew and Tropp, 2006). Indeed, positive personal encounters with immigrants improve outgroup attitudes among the national majority (e.g. McLaren, 2003; Voci and Hewstone, 2003). Personal encounters reduce fears associated with immigration, increase empathy and provide a more nuanced view of immigrants, which then improves attitudes (see Pettigrew and Tropp, 2008 for a meta-analysis; Swart et al., 2011).

Crucial for our argumentation, personal encounters with immigrants also provide insights into the understanding of the national ingroup. Such a reappraisal of the national ingroup results in deprovincialization, a reassessment of the importance of the ingroup and its traditions and ways of life (Pettigrew, 1997). Intergroup contact is notably shown to reduce identification with the nation (Kauff et al., 2016; Pettigrew, 2009), positive ingroup feelings (Verkuyten et al., 2010), and national pride (Pettigrew, 1997), considered to imply deprovincialization. Deprovincialization also involves seeing the national ingroup in a more complex manner by recognizing crosscutting and multiple group memberships (e.g. someone who shares my national identity, but has foreign origins (Brewer, 2008; Pettigrew, 2011). Lolliot et al. (2013) argued that endorsement of multiculturalism involves a reappraisal of the ingroup in terms of heightened tolerance and inclusion of minority identities and cultures, and thus is an expression of deprovincialization. They further demonstrated that endorsement of multiculturalism mediated the relationship between personal encounters with one outgroup and attitudes toward other outgroups.

Endorsement of an ethnic view of nationhood conveys impermeable boundaries between the national majority and immigrants, whereas the boundaries of the ingroup are more permeable when nationhood is not seen in ethnic terms (e.g. Lamont and Molnár, 2002; Wimmer, 2011). Reduced ethnic boundary making therefore denotes a reappraisal of the national ingroup that we consider a form of deprovincialization. In line with intergroup contact theory, personal encounters should favor deprovincialization.

- Hypothesis 1: Personal encounters with immigrant outgroups should relate to deprovincialization.

\section{Immigrant presence, ideological climate, and their interplay}

In multicultural societies, possibilities for encounters with immigrants are prevalent. Two competing lines of argumentation have been put forward to understand the relationship between immigrant presence and attitudes toward immigrants. Group threat theory contends that a high proportion of immigrants increase perceived threat, which fosters exclusive attitudes (e.g. Blalock, 1967; Scheepers et al., 2002). Intergroup contact theory, in contrast, reasons that immigrant presence increases opportunities for contacts with immigrants, thereby promoting positive attitudes toward them (Schlueter and Wagner, 2008; Wagner et al., 2006). Both contentions received empirical support. While there is evidence that the presence of immigrants is related to positive immigration attitudes in proximal contexts (e.g. Wagner et al., 2006), cross-national comparisons yielded evidence of an increased anti-immigration stance (for seminal research see McLaren, 2003; Meuleman et al., 2009; Quillian, 1995; Scheepers et al., 2002). Moreover, in a cross-national study, Wright (2011) found no relationship between presence of immigrants and ethnic boundary making. In a systematic comparison of immigrant presence in proximal vs distal regional geographical contexts, Weber (2015) demonstrated that presence of immigrants in proximal contexts was related to a positive stance on immigration, whereas the opposite was true when examining the impact of immigrant presence across large-scale units, nations. Immigrant presence on the country level does not necessarily result in personal, everyday encounters, for example, due to residential segregation 
(Semyonov and Glikman, 2009). Instead, some citizens are mainly exposed to the presence of immigrants through the mass media. In particular, the presence and increase of stigmatized immigrants is frequently framed in a threatening way in the media, thereby triggering antiimmigration attitudes (see Wagner et al., 2006; Weber, 2015).

Because we examine the impact of intergroup contact on deprovincialization, our focus is on immigrant presence in small-scale proximal geographical contexts. As different representations of nationhood coexist within a single nation-state, regardless of its official citizenship policy (e.g. Tilley et al., 2004), the investigation of within-country variation in deprovincialization or ethnic boundary making is relevant. Proximal geographical contexts (e.g. neighborhoods, districts) with a high presence of immigrants provide possibilities for everyday encounters with immigrants (e.g. Wagner et al., 2006; Weber, 2015). As reported above, immigrant presence in such contexts has been shown to relate to more positive attitudes toward immigrants (see Schlueter and Wagner, 2008; Schmid et al., 2014; Wagner et al., 2006). Moreover, in a recent study conducted in the Netherlands, Verkuyten et al. (2010) found that immigrant and ethnic minority presence in the classroom (another type of proximal context) relates to deprovincialization due to increasing support for multiculturalism. These findings suggest that the presence of immigrants reduces ethnic boundary making thereby prompting deprovincialization.

- Hypothesis 2: In small-scale proximal spatial units, greater immigrant ratio should relate to deprovincialization.

As immigrant presence is not static but a dynamic phenomenon (see Blalock, 1967), in the current study, we also consider change in the immigrant ratio. Rapid increases in immigration allow for more contact opportunities, but they may foster, even on a local level, ethnic conceptions of nationhood to ensure and bolster the boundaries between the national majority and immigrant groups (e.g. Laurence, 2014; Putnam, 2007). For example, across neighborhoods and districts in Madrid, Cebolla-Boado and Jiménez-Buedo (2011) found that increased immigration ratio related to a shift in support from left-wing parties to conservative right parties, though only during a time period when the immigrant ratio was high overall in the country (see Wright, 2011 for similar cross-national evidence concerning ethnic views of nationhood). This evidence lends itself to two alternative hypotheses.

- An increased immigrant ratio can relate to heightened (Hypothesis $3 a$ ) or reduced (Hypothesis 3b) deprovincialization.

Diversity does not occur in a vacuum, however. Ideological climates consist of prevailing societal norms, unwritten rules, which prescribe appropriate and approved views toward immigrant presence and societal inequalities in general. Our focus is on shared norms based on fellow ingroup members' views on societal topics (Crandall et al., 2002; see also Elcheroth et al., 2011; Staerklé et al., 2011). Such ideological climates shape majority members' attitudes toward immigrants and nationhood (Green and Staerklé, 2013; Guimond et al., 2014; Pehrson et al., 2009). In a crossnational study, Van Assche et al. (2017), for example, showed that regional and national right-wing climates, assessed with aggregated political orientations, predict anti-immigrant prejudice beyond individual ideological orientations, while Baur et al. (2016) demonstrated that conservative climates of cantons (aggregated conservative values in Swiss regions) predicted anti-immigration views and right-wing voting propensity beyond individual-level sociodemographic and attitudinal factors. Christ et al. (2014), in turn, revealed with several cross-national and within-country samples that contextual pro-diversity norms, assessed with aggregate attitudes, negatively related to 
prejudice. Members of the national majority are thus aware and guided by ideological climates validating viewpoints consistent with group norms.

Ideological climates can be more or less inclined to foster deprovincialization by means of reduced ethnic boundary making. Conservative ideological climates, embodying rejection of social change and endorsement of anti-egalitarian views, enforce status differences, whereas progressive ideological climates endorse social change and attenuate societal hierarchies (Fischer et al., 2012; Jost et al., 2003; Sidanius et al., 2004).

- Hypothesis 4: Deprovincialization should be greater in progressive ideological climates than in conservative climates.

Ideological climates do not guide individuals' views of nationhood under all circumstances. While there is evidence that both presence of immigrants and ideological climates affect immigrant outgroup and national ingroup attitudes, the interplay of these two factors remains understudied. Both theoretical considerations and empirical evidence (to our knowledge from the only two existing studies) point to opposing patterns. On the one hand, intergroup contact theory suggests that, in proximal contexts, the presence of immigrants blurs the boundaries of the national ingroup, and thereby increases permeability. The presence of immigrants should then counteract the deleterious effects of conservative climates, involving a vision of a hierarchical and conformist society. In line with this argument, Sarrasin et al. (2012) found that the negative relationship between conservative climates in Swiss municipalities and personal encounters with immigrants was attenuated by immigrant presence. On the other hand, the presence of immigrants or their increased presence, if threatening (see Meuleman et al., 2009), can also accentuate the impact of conservative climates. Providing evidence for this argument, Fasel et al. (2013) revealed that in the most conservative Swiss municipalities, anti-veil attitudes (i.e. seeing the veil as an obstacle for citizenship) increased as a function of proportion of immigrants from former Yugoslavia and from Turkey. We study whether immigrant presence and increase in immigrant presence shape, that is moderate, the relationship between conservative climates and ethnic boundary making as a form of deprovincialization. Based on the described opposing findings, two alternative predictions are derived. Note that, because similar arguments can be made for both the immigrant ratio and increase in the immigrant ratio interacting with ideological climate, we do not derive separate sets of hypotheses.

- Immigrant ratio and an increase in the ratio could either attenuate (Hypothesis $5 a$ ) or accentuate (Hypothesis $5 b$ ) the relationship between conservative climates and deprovincialization.

\section{Method}

We tested the outlined predictions with data drawn from the ISSP 2013 National Identity module across districts in Switzerland. Insofar as our theoretical focus is on the role intergroup contact and the opportunities for contact, we selected the smallest available proximal level spatial unit. Districts (total $N$ in Switzerland =159) are higher-order administrative units grouping municipalities. ${ }^{2}$

The ISSP survey in Switzerland is embedded in the MOSAiCH survey "Measurement and Observation of Social Attitudes in Switzerland" including specific questions on intergroup contact with immigrants in different domains that were not asked in other countries. We employed districtlevel immigrant ratio and change in that immigrant ratio as indicators of immigrant presence. A political system of direct democracy, where citizens vote several times a year on various topics, allowed tapping of the ideological climate of a district with referendum results. The ideological climate was thus composed of shared political views of the voting population within the district. 


\section{Participants}

The sample consisted of 1237 individuals. As only respondents declaring Swiss nationality were considered, the final sample was 1019 individuals from 136 Swiss districts $(86 \%$ of the total districts in Switzerland; $\left.N_{\text {district }}=1-67, M_{\text {district }}=38.31\right)$ spread across all 26 cantons.

Average age in the sample was 50.15 years $(S D=17.90)$ and 50.5 percent were female. The respondents had on average 11.18 years of education $(S D=3.38)$ and perceived their personal financial situation as rather good on a scale ranging from 1 (very good) to 5 (very bad) $(M=2.17$, $S D=0.72$ ). On a political orientation scale ranging from 1 (left) to 10 (right), respondents were on average in the middle of the political spectrum $(M=5.41, S D=1.84)$. These individual-level sociodemographic characteristics were included in the models when testing our predictions (Ceobanu and Escandell, 2010).

\section{Individual-level variables}

To assess the outcome variable indicating deprovincialization, ethnic conception of the nation, we considered the importance of a series of criteria for being truly Swiss. The question was introduced by "[S]ome people say that the following things are important for being truly Swiss. Others say they are not important. How important do you think each of the following is ..." and followed by eight criteria: to have been born in Switzerland, to have Swiss citizenship, to have lived in Switzerland for most of one's life, to be able to speak one of the national languages, to be Christian, to respect Swiss political institutions and laws, to feel Swiss, and to have Swiss ancestry. Responses ranged from 1 (very important) to 4 (not important at all). An exploratory factor analysis (maximum likelihood with oblimin rotation) yielded two factors with eigenvalues above 1, explaining 43 percent of variance. To be born in Switzerland, to have Swiss citizenship, to have lived in Switzerland for most of one's life, to be Christian and to have Swiss ancestry loaded exclusively on the first factor (factor loadings above .54). Speaking the language and respecting Swiss institutions loaded exclusively on the second factor (factor loadings above .46). Finally, to feel Swiss loaded on both factors (factor loading .39 on both factors). This factor structure was identical in the Swiss data of ISSP 2002/2003 (Heath et al., 2009; see also Kunovich, 2009; Reeskens and Hooghe, 2010). As access to nationality is very restrictive in Switzerland, we considered items loading on the first factor as representing an ethnic conception of the nation. ${ }^{3}$ We reverse-coded answers to create a composite score with higher values reflecting a more ethnic conception of the nation, that is, less deprovincialization (Cronbach's $\alpha=.81, M=2.68, S D=0.71$ ).

Intergroup contact, the individual-level predictor, was measured with five items, asking whether the respondent has personal encounters with immigrants in five different contexts (in the family, among friends, in associations, at the workplace, school or university, in the neighborhood). Responses ranged from 0 (never) to 5 (more than once a week). An exploratory factor analysis (maximum likelihood) yielded one factor with an eigenvalue above 1, explaining 50 percent of variance (factor loadings above .54). Responses to the five items were thus averaged to create a composite score with higher values representing more contact (Cronbach's $\alpha=.82, M=2.58, S D=1.33$ ). ${ }^{4,5}$

Missing data on the individual-level measures and sociodemographic characteristics were imputed with the EM algorithm in SPSS.

\section{District-level predictors}

Grand means, standard deviations, ranges, and correlations between variables at the district level are reported in Table 1. 
Table I. Descriptive statistics and correlations between variables at the district level $(N=\mid 36)$.

\begin{tabular}{lrrllll}
\hline & Mean (SD) & \multicolumn{1}{c}{ Range } & I & 2 & 3 & \multicolumn{1}{l}{4} \\
\hline I. Conservative climate (\%) & $73.86(6.13)$ & 52.97 to 84.57 & - & $-.34^{* * * *}$ & .03 & $.15^{\dagger}$ \\
2. Immigrant ratio (\%) & $20.72(7.36)$ & 5.90 to 45.40 & - & $.38^{* * *}$ & $-.23^{* *}$ \\
3. Change in immigrant ratio (\%) & $2.04(1.06)$ & -0.07 to 5.60 & & - & -.11 \\
4. Ethnic conception of nationhood & $2.73(0.40)$ & 1.80 to 4.00 & & & - \\
\hline
\end{tabular}

${ }_{t} p=.074 .{ }^{*} p<.05 .{ }^{* * *} p<.01 .{ }^{* * * * *} p<.001$.

The district-level immigrant ratio was calculated with data from the Swiss Federal Statistical Office (https://www.atlas.bfs.admin.ch/maps/13/fr/11857_90_89_70/19684.html; see Appendix 1 for a map displaying the immigrant ratio and the number of immigrants across districts in Switzerland).

To calculate district-level change in the immigrant ratio over 5 years, we subtracted the 2008 immigrant ratio from the 2013 immigrant ratio. ${ }^{6}$ In 134 of the 136 districts, the immigrant ratio increased, while in one district it decreased, and in one there was no change (see range in Table 1). The district-level $2008(M=18.69 \%, S D=7.02$; range=4.50-42.90) and 2013 immigrant ratios (see Table 1$)$ were highly correlated $(r=.99)$ suggesting that the trends of immigration were the same across districts.

To assess district-level conservative climates, we considered results of three referendums held in Switzerland in 2013 defining a conservative versus a progressive stance: (a) percentages of voters against abolition of compulsory military service (73.2\% of voters overall in Switzerland), (b) against a salary capping with a 1:12 ratio (i.e. within a company the salary of the employee who earns the most should be maximum 12 times the salary of the employee who earns the least; $65.3 \%$ of voters), and (c) supporting stricter asylum seeker laws (78.5\% of voters). We chose these three referenda to assess climate because they were held the same year as the ISSP survey data collection, and because the issue and party stance toward these referenda could be clearly classified as conservative versus progressive. District-level referendum results were submitted to a principal component analysis that revealed one factor explaining 84 percent of variance (factor loadings above .86). We averaged referendum results into a composite score with higher values reflecting a more conservative district-level climate (Cronbach's $\alpha=.90)$.

\section{Analytic strategy}

As the data were structured on two levels with individuals (level 1) nested within districts (level 2), we performed multilevel regression analyses (Hox, 2010) with MPlus 5.1 using maximum likelihood estimation with robust standard errors (MLR; Muthén and Muthén, [1998] 2009). Multilevel modeling allows simultaneously testing which part of the variation in individual-level outcome variables (ethnic conception of nationhood) is explained by individual-level effects (intergroup contact), and which part by district-level effects (conservative climate, immigrant ratio, immigrant ratio change). To ensure the estimation of precise covariance estimates in the multilevel analysis, we multiplied by 100 the measure of endorsement of an ethnic conception of the nationhood. Ethnic conception of the nationhood varied across districts $\left(\sigma^{2}=359.95, S E=124.10, p=.004\right.$; $\mathrm{ICC}=.07)$, indicating that a significant part of the total variance for this variable resulted from this clustering structure (i.e. the fact that respondents are located in districts). This indicates that conducting multilevel analyses is necessary: Neglecting the hierarchical structure of the data in subsequent analyses would underestimate the standard errors of the dependent variables and may result in erroneous confirmation of hypotheses (e.g. Hox, 2010). 
At the within-districts (i.e. individual) level, we investigated the effect of intergroup contact (independent variable) on the ethnic conception of the nationhood (outcome variable). Control variables - that is, sex, age, education, perceived personal economic situation, and political orientation - were included in the model. At the between-districts level, we examined the effects of the immigrant ratio, of change in the immigrant ratio, as well as of conservative climate on ethnic conception of the nation. To model the predicted level-2 interactions (conservative climate $\mathrm{x}$ immigrant ratio; conservative climate $\mathrm{x}$ immigrant ratio change), we grand-mean centered district-level predictors prior to the analysis.

\section{Results}

\section{Model building}

In the lower panel of Table 2, we examined whether adding variables to the model at each step improved the model fit. As the models were nested, we examined the difference in deviance with $\chi^{2}$-distributed $-2 * \operatorname{Ln}($ likelihood) test (corrected with the scaling factor necessary for MLR estimations; Satorra and Bentler, 2001). Compared to the baseline model (Model 0), entering all individual-level predictors in Model 1 improved the model fit: That is, model deviance decreased significantly. The fit further improved when including district-level predictors in Model 2, indicating that district-level effects occurred over and above the individual-level effects. We added district-level interactions one by one to Model 2 . Only the immigrant ratio $\times$ conservative climate interaction improved the model fit (Model 3). Adding the immigrant ratio change $\times$ conservative climate interaction to Model 3 did not further improve the model, $\Delta \chi^{2}(1)=0.32, p=.572 .{ }^{7}$

Note also that a substantial part of the differences between districts was driven by their different socio-demographic compositions (37\% district-level explained variance in Model 1 out of $57 \%$ in Model 3). However, after accounting for these compositional effects, district-level variables and the immigrant ratio $\times$ conservative climate interaction explained significant parts of district-level variation.

\section{Hypothesis testing}

Next, we examined the coefficients of the multilevel regression analyses in the upper panel of Table 2. As predicted (Hypothesis 1), Model 1 revealed that intergroup contact was negatively related to perceiving nationhood in ethnic terms. That is, encounters with immigrant outgroup members related to deprovincialization. ${ }^{8}$

The examination of the regression coefficients of the control variables indicated, similar to prior research (Ceobanu and Escandell, 2010), that women more than men, older people, less educated and those with a more right-wing orientation endorsed an ethnic conception of the nationhood. Perception of economic situation, however, was unrelated to an ethnic conception of nationhood.

In line with Hypothesis 2, over and above individuals' contact experiences and sociodemographic characteristics, Model 2 showed, albeit marginally $(p=.083)$, that the immigrant ratio was negatively related to perceiving nationhood in ethnic terms on the district level. Hypothesis $3 a b$ and Hypothesis 4 were disconfirmed: When entered simultaneously to the model, both immigrant ratio change and conservative climate were unrelated to the ethnic conception of the nation. Note, however, that, when entered one by one to the model, the district-level indicators were related, though sometimes marginally, to the ethnic conception of nationhood. In line with intergroup contact theory, the immigrant ratio $(b=-0.88, S E=0.34, p=.010)$ and the immigrant ratio increase $(b=-4.30, S E=2.45, p=.079)$ were related to a reduced ethnic conception of nationhood 
Table 2. Unstandardized multilevel regression coefficients and standard errors for individual and contextual predictors of ethnic conception of the nation.

\begin{tabular}{|c|c|c|c|}
\hline & $\begin{array}{l}\text { Model I } \\
\text { Individual-level } \\
\text { predictors }\end{array}$ & $\begin{array}{l}\text { Model } 2 \\
\text { District-level } \\
\text { predictors }\end{array}$ & $\begin{array}{l}\text { Model } 3 \\
\text { District-level } \\
\text { interactions }\end{array}$ \\
\hline Intercept & $232.06(16.48)^{* * * *}$ & $227.35(16.72)^{* * *}$ & $225.99(16.39)^{\text {**** }}$ \\
\hline \multicolumn{4}{|l|}{ Individual-level predictor } \\
\hline Intergroup contact & $-12.68(1.83)^{* * *}$ & $-12.30(1.89)^{* * *}$ & $-12.36(1.87)^{* * *}$ \\
\hline \multicolumn{4}{|l|}{ Individual-level controls } \\
\hline Female & $12.88(3.78)^{* * *}$ & $13.24(3.72)^{* * *}$ & $13.08(3.75)^{* * *}$ \\
\hline Age & $0.66(0.12)^{* * *}$ & $0.68(0.13)^{* * *}$ & $0.69(0.13)^{* * *}$ \\
\hline Years of education & $-2.90(0.59)^{* * *}$ & $-2.75(0.59)^{* * * *}$ & $-2.76(0.59)^{* * *}$ \\
\hline Economic situation & $-3.67(2.59)$ & $-2.87(2.59)$ & $-2.86(2.58)$ \\
\hline Political orientation & $10.64(1.02)^{* * *}$ & $10.54(1.05)^{* * *}$ & $10.58(1.03)^{* * *}$ \\
\hline \multicolumn{4}{|l|}{ District-level predictors } \\
\hline Conservative climate & & $0.36(0.36)$ & $0.59(0.4 I)$ \\
\hline Immigrant ratio & & $-0.63(0.36)^{\dagger}$ & $-0.95(0.42)^{*}$ \\
\hline Immigrant ratio change & & $-2.13(2.36)$ & $-0.94(2.27)$ \\
\hline Conservative climate $\mathrm{x}$ Immigrant ratio & & & $-0.08(0.04)^{*}$ \\
\hline \multicolumn{4}{|l|}{ Variance components } \\
\hline \% explained variance: individual level & $28.33 \%$ & & \\
\hline \% explained variance: district level & $37.16 \%$ & $51.77 \%$ & $57.38 \%$ \\
\hline Corrected $\Delta-2 * \ln (\Delta d f)$ & $286.69(6)^{* * *}$ & $10.58(3)^{*}$ & $5.06(I)^{*}$ \\
\hline
\end{tabular}

Unstandardized coefficients are reported. Standard errors are in parentheses.

In Model 0, intercept is 270.82 (3.II) ${ }^{* * * ;} ;-2 * I n$ (deviance) = II 572.68 ; individual-level variance is $4745.6 \mathrm{I} * * * ;$ district-level variance is $359.95^{* *}$.

$\dagger_{p}=.083 . * p<.05 . * * p<.01 . * * * p \leqslant .001$.

(revealing deprovincialization). Conservative climate, in turn, was related to an increased ethnic conception of nationhood $(b=0.71, S E=0.38, p=.062) .{ }^{9}$

Finally, Model 3 revealed an interaction between conservative ideological climate and immigrant ratio. We decomposed the level-2 interaction using simple slope analyses (Preacher et al., 2006). In support of intergroup contact theory (Hypothesis 5a), the immigrant ratio buffered the effect of conservative climates. Figure 1 shows that a conservative climate was positively associated to an ethnic conception of nationhood only in districts with a low ratio of immigrants $(M-1$ $S D, b=1.19, S E=0.63, p=.059)$. In districts with a high ratio of immigrants $(M+1 S D)$, conservative climate and ethnic conception of nationhood were unrelated $(b=-0.01, S E=0.40, p=.973) .{ }^{10,11}$

\section{Discussion}

With a multilevel study set in Switzerland, the current paper examined the impact of individualand district-level characteristics on ethnic boundary making. Bringing together literature on ethnic boundary making and intergroup contact, we investigated how personal encounters with immigrants, immigrant presence, and the surrounding ideological climate shape the way national majority members construe boundaries of the ingroup. In support of intergroup contact theory, we demonstrated that personal encounters with immigrants related to deprovincialization, here operationalized with reduced support for ethnic-based criteria for nationhood. This finding suggests a 


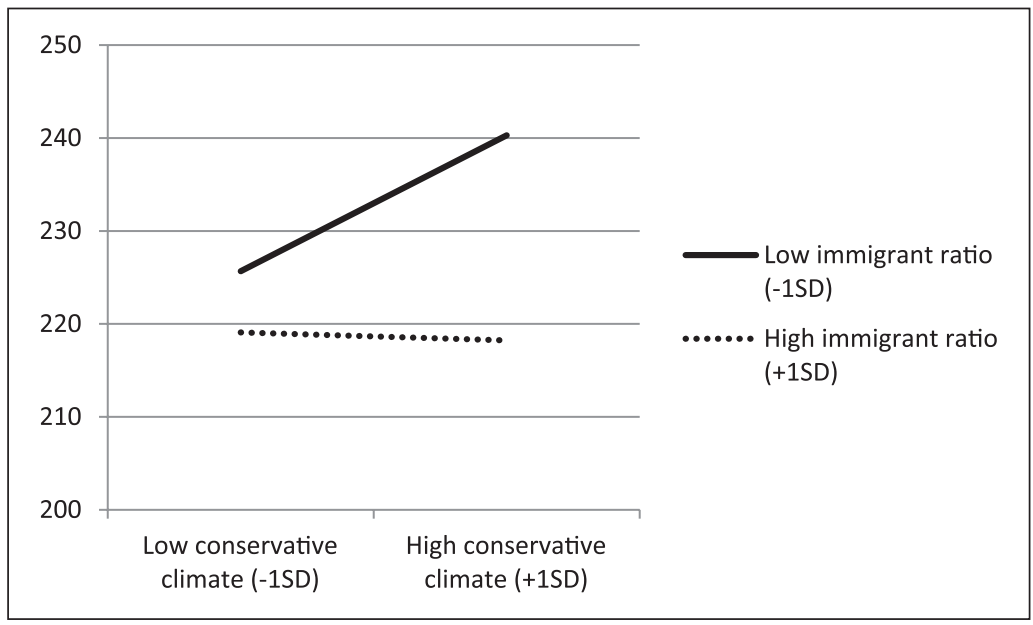

Figure I. Ethnic conception of the nation as a function of district-level conservative climate and immigrant ratio.

reappraisal of the ingroup, such that the boundaries of the national group become more permeable. Immigrant ratio was also related to deprovincialization, albeit marginally, while increase in immigrant ratio was unrelated. As the proportion of immigrants is historically high in Switzerland (Piguet, 2009; highest in Europe after Luxemburg), the slight increase that occurred throughout the districts (in 134 of the 136 Swiss districts with an average increase of $2.04 \%$, see also Table 1) may have gone unnoticed. For example, if the immigrant ratio is 30 percent, a 2 percent increase is likely to be hardly perceivable. ${ }^{12}$

We also examined how ideological climate - that is, what other ingroup members in one's surroundings think of societal topics - shapes support for ethnic-based criteria for nationhood. Multilevel survey research on the impact of ideological climates on immigrant outgroup attitudes has up to now been scant. To our knowledge, this study was the first examining the relationship between ideological climate and ethnic boundary making, and crucially revealed that normative and structural characteristics of contexts act in concert in this process. Ideological climates denote the normative context in which formation of public opinion takes place. In the current study, ideological climates were measured by how ingroup members within a district express via referendums their views concerning societal issues. The impact of the ideological climate on ethnic boundary making should depend on whether opportunities for contact with immigrants exist. Indeed, we predicted and found an interaction between immigrant presence and ideological climate. While prior research lent itself for alternative predictions, our findings spoke in favor of the intergroup contact theorizing. Conservative climates related to ethnic boundary making, that is less deprovincialization, but only when immigrant presence was low. The key novelty of the article was the demonstration that the presence of immigrants buffered the pernicious effects of conservative local climates. In the following, we discuss possible extensions and shortcomings of this line of research.

Future research on the interplay of immigrant presence and ideological climates should be conducted in other countries and with other assessments of ideological climates (see Wimmer, 2011 for the specificity of Switzerland in national boundary making). Indeed, specific for Switzerland, direct democracy is a political system involving frequent referendums, used in the current study to tap the ideological climate. Shared ideological climates can alternatively be measured with aggregate political attitudes (see Christ et al., 2014; Van Assche et al., 2017). Moreover, we conceptualized 
ideological climates as shared views on societal topics summarizing the standpoints of other ingroup members within individuals' proximal geographical space. But institutionalized norms, in the form of integration and citizenship policies, have also been shown to predict attitudes toward immigration both within countries (Baur et al., 2016 for Swiss cantonal policies), and across countries (Schlueter et al., 2013; Visintin et al., 2018; Weldon, 2006). In some cases, shared and institutional norms yield similar effects (Baur et al., 2016) in others not (Schlueter et al., 2013). Future research would thus do well to consider whether immigrant presence moderates the effects of institutional and shared ideological climates in a similar or different manner when predicting deprovincialization, and attitudes toward immigration more generally.

In this study, we assessed the impact of the overall presence of immigrants. Yet, the type of immigrant presence also matters. Distinguishing different immigrant groups may help further pinpoint when the presence of immigrants buffers the impact of ideological climates on ethnicitybased stances of nationhood. Immigrants originating from culturally close countries are usually not considered threatening (see Ford, 2011; see however Helbling, 2011 on Swiss Germans' attitudes toward Germans). Encounters with stigmatized immigrants originating from culturally different countries are more difficult due to constraints in communication and pre-existing stereotypes (see also Laurence, 2014; Schneider, 2008). Indeed, network research in the Netherlands and Belgium supports this interpretation by revealing ethnic boundaries in national majority students' friendship networks (Baerveldt et al., 2007): Intra-ethnic friendships were denser than interethnic friendships. Moreover, in a study comparing Swiss municipalities, Green et al. (2010) found that the presence of culturally close, Western European immigrants positively related to intergroup contact, which in turn was related to reduced threat perceptions and exclusive attitudes. The presence of highly stigmatized immigrants, from Muslim countries, in turn, elicited both threat perceptions and increased intergroup contact (see also Fasel et al., 2013; Rapp, 2015). García-Faroldi (2017) further demonstrated, in a cross-national study across Europe, that while the overall immigrant ratio was related to reduced tolerance, the proportion of culturally close immigrants (EU-15 immigrants) was related to increased tolerance. As the opportunities for contact are easier to seize with "valued" and culturally close immigrants, the buffering effects of immigrant presence should be stronger. To explore these considerations, we reran the model of the current paper when immigrant presence distinguished between culturally close, Western European immigrants and immigrants from Africa, former Yugoslavia and Albania, the most discriminated against immigrant groups in Switzerland (SFSO, 2014). Replicating the result pattern (see Appendix 2 Model 7), the presence of culturally close immigrants was related to deprovincialization and buffered the impact of ideological climate. The presence of stigmatized immigrants was unrelated to deprovincialization and did not interact with ideological climate. These findings suggest that firmer conclusions can be drawn regarding the buffering effect of culturally close immigrants, instead of immigrants in general. Indeed, the meta-analysis of Pottie-Sherman and Wilkes (2015) shows that the impact of stigmatized or racialized minorities on attitudes was smaller than that of immigrants in general. The finding of these additional analyses may also be due to the structure of immigration in Switzerland with a relatively larger proportion of Western European than stigmatized immigrants (13\% vs $4.4 \%$ across the districts in this study). Despite the challenges of examining the impact of distinct immigrant groups, notably due to differing settlement patterns within countries, future research should pursue this direction when examining the moderating impact of presence of immigrants.

The broader notion of interculturalism, a new framing of interethnic relations, also resonates with intergroup contact, the key theoretical concept of this article. Both bring social relationships to the fore. Interculturalism involves coexistence, dialogue and cohesive interactions between immigrants and national majorities (Bello and Bloom, 2017) and relates to increased tolerance (Bello, 2017). Considering intergroup contact in this broader framework may allow interpreting 
the varying effects of different immigrant groups. As the prejudice-inducing effect of negative encounters is shown to be greater than the prejudice-reducing effect of positive encounters (Barlow et al., 2012), to further understand the challenges of coexistence and dialogue, future research should examine both negative and positive contact experienced with culturally close as well as culturally distant, stigmatized immigrants.

As always with cross-sectional surveys, the current findings do not allow us to draw firm causal claims. Existing experimental and longitudinal research have amply theorized and evidenced the causal mechanisms explaining the impact of contact (e.g. Page-Gould et al., 2008; Swart et al., 2011) and of ideological climates (e.g. Falomir-Pichastor et al., 2004) on immigration attitudes thereby increasing our confidence in these findings. Nevertheless, longitudinal survey designs in future research would be ideal for examining whether immigrant presence and ideological climate and their interaction predict deprovincialization over time. With such a design, one could also examine the effects of change in immigrant presence and in ideological climates. Moreover, experiments simultaneously manipulating immigrant presence and the ideological climate with vignettes would allow to pinpoint the mechanisms that explain the buffering effect of immigrant presence (e.g. reported contact experiences or intentions). For example, Falomir-Pichastor et al. (2004) experimentally induced a surrounding ideological climate by portraying fictitious survey findings, where the majority of nationals convey either egalitarian or anti-egalitarian viewpoints. Conducting such experiments in different contexts would further allow generalization from the findings. Taking a mixed-methods approach, process tracing would be yet another way of tapping into causal mechanisms (Beach, 2017) and complementing the findings revealed in the current multilevel regression analysis. To test intergroup contact theorizing with process tracing could involve interviewing individuals (cases), who displayed deprovincialization, in districts with conservative climates with either low or high immigrant presence. Interviews would first tap into individuals' subjective impressions of the ideological climate and immigrant presence, then focus on contact experiences and intentions (one potential mechanism). Such interviews might finally examine the extent to which contact experiences relate to affective expressions (such as reduction of anxiety and threat or increase of empathy) frequently theorized in intergroup contact literature as the social psychological mechanisms explaining the beneficial effects of contact (see Pettigrew and Tropp, 2008).

Notwithstanding the caveats of this study and the outlined directions for further research, this article revealed the interplay of immigrant presence and ideological climates in shaping reappraisal of national ingroup boundaries. We showed that intergroup contact relates to deprovincialization, and that immigrant presence buffered the effects of conservative ideological climates. Attitudes toward immigration and the national ingroup are shaped by changes in ideological landscapes resulting from societal phenomena (e.g. the refugee crisis) and in political structure (e.g. which parties are in power), and the way these changes are framed by politicians and the media. It is thus urgent to understand the role of ideological climate when assessing the influence of immigrant presence on anti-immigrant attitudes in Europe and beyond.

\section{Funding}

The research was funded by Swiss National Science Foundation SNF Division 1 (100014_159336/1) and nccr - On the move grants to Eva G. T. Green and Juan Manuel Falomir-Pichastor.

\section{Notes}

1. Ethnic criteria of nationhood are opposed to civic criteria based on common citizenship and participation in public life (e.g. political ideology and rights), rather than on blood ties or religion (Kunovich, 2009; Shulman, 2002). Note that, ethnic criteria are sometimes considered to confound ethnic (ancestry) and 
non-political cultural criteria (Shulman, 2002). The ethnic-civic distinction used to describe citizenship regimes (Brubaker, 1992) is also criticized for the lack of nuance in different regimes (see Koopmans et al., 2005).

2. The Swiss ISSP has used one-stage random sampling since 2010. That is, individuals are drawn randomly from the sampling register of the Swiss Federal Statistical Office. Because of that, 72 percent of the municipalities in the sample had only one respondent $(N$ municipalities $=629 ; N$ per municipality ranged from 1 to $42 ; M=1.61$ ).

3. Additional analyses assessing the hypothesized model with the second factor (civic criteria) as the outcome revealed no district-level effects.

4. The survey included additional items assessing separately the frequency of positive and negative contact with immigrants across the five contexts (see Barlow et al., 2012, for the distinction between positive and negative contact episodes). However, only respondents reporting contacts with immigrants were asked these questions. Our focus was on the impact of frequency of intergroup contact on deprovincialization, that is, on the effects of having contact versus not. Using positive and negative contact as predictors in the multilevel regression analysis was not viable: This would have excluded all respondents reporting no intergroup contact from the sample (reduced $N_{\mathrm{s}}=417-780$ ). Responses to these items, however, give insights about the valence of intergroup contact. Assessed on scales ranging from 1 (never) to 5 (very often), positive contacts (across the five contact domains $M_{\text {range }}=3.72-4.27$ ) were more frequent than negative contacts (across the five contact domains $M_{\text {range }}=1.46-1.88$ ), $t \mathrm{~s}>34.00, p \mathrm{~s}<.001$.

5. Confirmatory factor analyses (MLR estimation with robust standard errors) were conducted to ensure that intergroup contact and endorsement of ethnic nationhood were distinct constructs. Indeed, while a two-factor model yielded a good fit, Satorra-Bentler scaled $\chi^{2}(34)=146.59, p<.001$, CFI $=.96$, RMSEA $=0.061$, the model fit for a one-factor model was poor, Satorra-Bentler scaled $\chi^{2}(35)=1229.53$, $p<.001, \mathrm{CFI}=.61, \mathrm{RMSEA}=0.19$.

6. The composition of the districts within three Swiss cantons changed between 2008 and 2013. For these cantons, we first matched municipalities in 2008 with district composition in 2013. Next, we calculated the 2008 immigrant ratio by aggregating municipality-level immigration data based on the district composition in 2013.

7. Note that when the immigrant ratio change $\times$ ideological climate interaction was added to Model 2 (i.e. without the immigrant ratio $\times$ ideological climate term), there was a marginally significant improvement of the model, $\Delta \chi^{2}(1)=3.18, p=.074$. The interaction effect, however, was not significant, $p=.120$ (see Appendix 2 Model 4).

8. We wanted to ensure that the effect was not solely driven by intergroup friendships (see, for example, Manevska et al., 2017), considered one of the most powerful ways to reduce prejudice (Davies et al., 2011). We ran five additional models, with the single item of each of the five domains of contact (family, friendships, association, workplace, neighborhood) as individual-level predictor. Each domain of contact was significantly related to reduced ethnic boundary making (i.e. deprovincialization), and all other result patterns remained identical.

9. The presence of immigrants frequently predicts intergroup contact (see Schlueter and Wagner, 2008; Wagner et al., 2006), therefore intergroup contact may mediate the relationship between immigrant ratio and ethnic conception of nationhood. In additional analyses, we modeled cross-level indirect effects from immigrant ratio and increase in immigrant ratio to endorsement of ethnic nationhood through district-level intergroup contact. No indirect effects were revealed, because district-level contact and endorsement of ethnic nationhood were unrelated $(b=-9.04, S E=12.44, p=.467)$. Yet, as intergroup contact theory would suggest, the immigrant ratio was positively related to district-level contact $(b=0.03$, $S E=0.006, p<.001)$ : That is, the first part of the 2-1-1 mediation chain was statistically significant. Immigrant ratio increase instead was unrelated to district-level contact $(b=-0.03, S E=0.05, p=.537)$.

10. It is also plausible that conservative climates and presence of immigrants have less impact on individuals with personal encounters with immigrants (see Laurence, 2014; McLaren, 2003; Schneider, 2008; Semyonov and Glikman, 2009 for findings on the interactions between immigrant presence and personal encounters with immigrants). Modeling cross-level interactions allowed testing for such predictions. However, preliminary analyses revealed that the slope (i.e. the relationship) between intergroup 
contact and endorsement of ethnic definitions of nationhood did not vary significantly across districts, $\sigma^{2}=15.27, \mathrm{SE}=18.89, p=.42$, and the cross-level interactions were not statistically significant (see Appendix 2 Model 5).

11. One of the three referenda used to assess conservative climate concerned immigration (restricting asylum laws), while the other two referenda were unrelated to immigration. To ensure that our findings were not driven only by the referendum about asylum laws, we ran three additional models. In each of these models, conservative climate was assessed by results of a single referendum. The results patterns were identical in essence to the main model, that is, yielding an interaction between conservative climate and immigrant ratio (stricter asylum seeker laws $p=.067$; salary capping $p=.039$; mandatory military service $p=.055)$.

12. Moreover, as previous and present immigrant ratios were almost perfectly correlated, similar changes occurred across districts. This suggests that, in Switzerland during the time period examined in this study, increase in the immigrant ratio was not a relevant predictor. Note that when change of immigrant ratio was excluded from the model the result pattern remained identical (see Appendix 2 Model 6).

\section{ORCID iD}

Eva GT Green (iD) https://orcid.org/0000-0003-1516-0157

\section{References}

Allport GW (1954) The Nature of Prejudice. New York: Addison-Wesley.

Anderson B (2006) Imagined Communities: Reflections on the Origin and Spread of Nationalism. London: Verso.

Baerveldt C, Zijlstra B, De Wolf M, et al. (2007) Ethnic boundaries in high school students' networks in Flanders and the Netherlands. International Sociology 22(6): 701-720.

Bail CA (2008) The configuration of symbolic boundaries against immigrants in Europe. American Sociological Review 73(1): 37-59.

Barlow FK, Paolini S, Pedersen A, et al. (2012) The contact caveat: Negative contact predicts increased prejudice more than positive contact predicts reduced prejudice. Personality and Social Psychology Bulletin 38(12): 1629-1643.

Baur R, Green EGT and Helbling M (2016) Immigration-related political culture and support for radical right parties. Journal of Ethnic and Migration Studies 42(11): 1748-1773.

Beach D (2017) Process-tracing methods in social science. In: Thompson WR (ed.) Oxford Research Encyclopedias of Politics. Oxford: Oxford University Press.

Bello V (2017) Interculturalism as a new framework to reduce prejudice in times of crisis in European countries. International Migration 55(2): 23-38.

Bello V and Bloom T (2017) Interculturalism in times of crisis. International Migration 55(2): 5-9.

Blalock HM (1967) Toward a Theory of Minority-group Relations. London: Wiley.

Brewer MB (2008) Deprovincialization: Social identity complexity and outgroup acceptance. In Ulrich W, Tropp LR, Finchilescu G, et al. (eds) Improving Intergroup Relations: Building on the Legacy of Thomas F. Pettigrew. Malden, MA: Blackwell Publishing, pp. 160-176.

Brubaker R (1992) Citizenship and Nationhood in France and Germany. Cambridge, MA: Harvard University Press.

Cebolla-Boado H and Jiménez-Buedo M (2011) Immigration and the vote for the left: Measuring the effect of ethnic diversity on electoral outcomes at the district level. International Journal of Comparative Sociology 52(1-2): 132-153.

Ceobanu AM and Escandell X (2010) Comparative analyses of public attitudes toward immigrants and immigration using multinational survey data: A review of theories and research. Annual Review of Sociology 36: 309-328.

Christ O, Schmid K, Lolliot S, et al. (2014) Contextual effect of positive intergroup contact on outgroup prejudice. Proceedings of the National Academy of Sciences 111(11): 3996-4000. 
Cohrs JC and Stelzl M (2010) How ideological attitudes predict host society members' attitudes toward immigrants: Exploring cross-national differences. Journal of Social Issues 66(4): 673-694.

Crandall CS, Eshleman A and O'brien L (2002) Social norms and the expression and suppression of prejudice: The struggle for internalization. Journal of Personality and Social Psychology 82(3): 359-378.

Davies K, Tropp LR, Aron A, et al. (2011) Cross-group friendships and intergroup attitudes: A meta-analytic review. Personality and Social Psychology Review 15(4): 332-351.

Elcheroth G, Doise W and Reicher S (2011) On the knowledge of politics and the politics of knowledge: How a social representations approach helps us rethink the subject of political psychology. Political Psychology 32(5): 729-758.

Falomir-Pichastor JM, Muñoz Rojas D, Invernizzi F, et al. (2004) Perceived in-group threat as a factor moderating the influence of in-group norms on discrimination against foreigners. European Journal of Social Psychology 34(2): 135-153.

Fasel N, Green EGT and Sarrasin O (2013) Unveiling naturalization: A multilevel study on minority proportion, conservative ideologies, and attitudes toward the Muslim veil. Zeitschrift für Psychologie 221(4): $242-251$.

Fischer R, Hanke K and Sibley CG (2012) Cultural and institutional determinants of social dominance orientation: A cross-cultural meta-analysis of 27 societies. Political Psychology 33(4): 437-467.

Ford R (2011) Acceptable and unacceptable immigrants: How opposition to immigration in Britain is affected by migrants' region of origin. Journal of Ethnic and Migration Studies 37(7): 1017-1037.

García-Faroldi L (2017) Determinants of attitudes towards immigration: Testing the influence of interculturalism, group threat theory and national contexts in time of crisis. International Migration 55(2): 10-22.

Green EGT (2009) Who can enter? A multilevel analysis on public support for immigration criteria across 20 European countries. Group Processes \& Intergroup Relations 12(1): 41-60.

Green EGT and Staerklé C (2013) Migration and multiculturalism. In: Huddy L, Sears DO and Levy JS (eds) Oxford Handbook of Political Psychology. Oxford: Oxford University Press, pp. 852-889.

Green EGT, Fasel N and Sarrasin O (2010) The more the merrier? The effects of type of cultural diversity on exclusionary immigration attitudes in Switzerland. International Journal of Conflict and Violence 4(2): 177-190.

Guimond S, de la Sablonnière R and Nugier A (2014) Living in a multicultural world: Intergroup ideologies and the societal context of intergroup relations. European Review of Social Psychology 25(1): 142-188.

Hainmueller J and Hangartner D (2013) Who gets a Swiss passport? A natural experiment in immigrant discrimination. American Political Science Review 107(1): 159-187.

Heath A, Martin J and Spreckelsen T (2009) Cross-national comparability of survey attitude measures. International Journal of Public Opinion Research 21(3): 293-315.

Helbling M (2011) Why Swiss-Germans dislike Germans: Opposition to culturally similar and highly skilled immigrants. European Societies 13(1): 5-27.

Hewstone M and Swart H (2011) Fifty-odd years of inter-group contact: From hypothesis to integrated theory. British Journal of Social Psychology 50(3): 374-386.

Hox JJ (2010) Multilevel Analysis: Techniques and Applications. New York: Routledge.

Huddy L and Khatib N (2007) American patriotism, national identity, and political involvement. American Journal of Political Science 51(1): 63-77.

Jost JT, Glaser J, Kruglanski AW, et al. (2003) Political conservatism as motivated social cognition. Psychological Bulletin 129: 339-375.

Kauff M, Schmid K, Lolliot S, et al. (2016) Intergroup contact effects via ingroup distancing among majority and minority groups: Moderation by social dominance orientation. PLoS ONE 11(1): e0146895.

Koopmans R, Statham P, Giugni M, et al. (2005) Contested Citizenship: Immigration and Ethnic Relations Politics in Europe. Minneapolis, MN: University of Minnesota Press.

Kunovich RM (2009) The sources and consequences of national identification. American Sociological Review 74(4): 573-593.

Lamont M and Molnár V (2002) The study of boundaries in the social sciences. Annual Review of Sociology 28(1): 167-195.

Laurence J (2014) Reconciling the contact and threat hypotheses: Does ethnic diversity strengthen or weaken community inter-ethnic relations? Ethnic and Racial Studies 37(8): 1328-1349. 
Lolliot S, Schmid K, Hewstone M, et al. (2013) Generalized effects of intergroup contact: The secondary transfer effect. In: Hodson G and Hewstone M (eds) Advances in Intergroup Contact. London: Psychology Press, pp. 81-112.

McLaren LM (2003) Anti-immigrant prejudice in Europe: Contact, threat perception, and preferences for the exclusion of migrants. Social Forces 81(3): 909-936.

Manevska K, Achterberg P and Houtman D (2017) Why there is less supportive evidence for contact theory than they say there is: A quantitative cultural-sociological critique. American Journal of Cultural Sociology 6: 296-321.

Meuleman B, Davidov E and Billiet J (2009) Changing attitudes toward immigration in Europe, 2002-2007: A dynamic group conflict theory approach. Social Science Research 38(2): 352-365.

Muthén LK and Muthén B ([1998] 2009) Mplus User's Guide, 5th edn. Los Angeles, CA: Muthén \& Muthén.

Page-Gould E, Mendoza-Denton R and Tropp LR (2008) With a little help from my cross-group friend: Reducing anxiety in intergroup contexts through cross-group friendship. Journal of Personality and Social Psychology 95(5): 1080-1094.

Pehrson S, Vignoles VL and Brown R (2009) National identification and anti-immigrant prejudice: Individual and contextual effects of national definitions. Social Psychology Quarterly 72(1): 24-38.

Pettigrew TF (1997) Generalized intergroup contact effects on prejudice. Personality and Social Psychology Bulletin 23(2): 173-185.

Pettigrew TF (2009) Secondary transfer effect of contact: Do intergroup contact effects spread to noncontacted outgroups? Social Psychology 40(2): 55-65.

Pettigrew TF (2011) Deprovincialization. In: Christie DJ (ed.) The Encyclopedia of Peace Psychology (Online Resource). New York: Wiley.

Pettigrew TF and Tropp LR (2006) A meta-analytic test of intergroup contact theory. Journal of Personality and Social Psychology 90(5): 751-783.

Pettigrew TF and Tropp LR (2008) How does intergroup contact reduce prejudice? Meta-analytic tests of three mediators. European Journal of Social Psychology 38(6): 922-934.

Piguet E (2009) L'immigration en Suisse: Soixante ans d'entrouverture. Lausanne: Presses polytechniques et universitaires romandes.

Pottie-Sherman Y and Wilkes R (2015) Does size really matter? On the relationship between immigrant group size and anti-immigrant prejudice. International Migration Review 51(1): 218-250.

Preacher KJ, Curran PJ and Bauer DJ (2006) Computational tools for probing interactions in multiple linear regression, multilevel modeling, and latent curve analysis. Journal of Educational and Behavioral Statistics 31(4): 437-448.

Putnam RD (2007) E pluribus unum: Diversity and community in the twenty-first century the 2006 Johan Skytte Prize Lecture. Scandinavian Political Studies 30(2): 137-174.

Quillian L (1995) Prejudice as a response to perceived group threat: Population composition and anti-immigrant and racial prejudice in Europe. American Sociological Review 60(4): 586-611.

Rapp C (2015) More diversity, less tolerance? The effect of type of cultural diversity on the erosion of tolerance in Swiss municipalities. Ethnic and Racial Studies 38(10): 1779-1797.

Reeskens T and Hooghe M (2010) Beyond the civic-ethnic dichotomy: Investigating the structure of citizenship concepts across thirty-three countries. Nations and Nationalism 16(4): 579-597.

Sarrasin O, Green EGT, Fasel N, et al. (2012) Opposition to antiracism laws across Swiss municipalities: A multilevel analysis. Political Psychology 33(5): 659-681.

Satorra A and Bentler PM (2001) A scaled difference chi-square test statistic for moment structure analysis. Psychometrika 66(4): 507-514.

Scheepers P, Gijsberts M and Coenders M (2002) Ethnic exclusionism in European countries. Public opposition to civil rights for legal migrants as a response to perceived ethnic threat. European Sociological Review 18(1): 17-34.

Schlueter E and Wagner U (2008) Regional differences matter: Examining the dual influence of the regional size of the immigrant population on derogation of immigrants in Europe. International Journal of Comparative Sociology 49(2-3): 153-173.

Schlueter E, Meuleman B and Davidov E (2013) Immigrant integration policies and perceived group threat: A multilevel study of 27 Western and Eastern European countries. Social Science Research 42(3): 670-682. 
Schmid K, Ramiah AA and Hewstone M (2014) Neighborhood ethnic diversity and trust: The role of intergroup contact and perceived threat. Psychological Science 25(3): 665-674.

Schneider SL (2008) Anti-immigrant attitudes in Europe: Outgroup size and perceived ethnic threat. European Sociological Review 24(1): 53-67.

Semyonov M and Glikman A (2009) Ethnic residential segregation, social contacts, and anti-minority attitudes in European societies. European Sociological Review 25(6): 693-708.

SFSO (2014) Integrations indikatoren. Available at: https://www.bfs.admin.ch/bfs/de/home/statistiken/bevoelkerung/migration-integration/integrationindikatoren.html

Shulman S (2002) Challenging the civic/ethnic and West/East dichotomies in the study of nationalism. Comparative Political Studies 35(5): 554-585.

Sidanius J, Feshbach S, Levin S, et al. (1997) The interface between ethnic and national attachment: Ethnic pluralism or ethnic dominance? The Public Opinion Quarterly 61(1): 102-133.

Sidanius J, Pratto F, Van Laar C, et al. (2004) Social dominance theory: Its agenda and method. Political Psychology 25(6): 845-880.

Smith AD (1991) National Identity. Reno, NV: University of Nevada Press.

Staerklé C, Clémence A and Spini D (2011) Social representations: A normative and dynamic intergroup approach. Political Psychology 32(5): 759-768.

Swart H, Hewstone M, Christ O, et al. (2011) Affective mediators of intergroup contact: A three-wave longitudinal study in South Africa. Journal of Personality and Social Psychology 101(6): 1221-1238.

Tilley J, Exley S and Heath A (2004) Dimensions of British identity. In: Park A, Curtice J, Thomson K, et al. (eds) British Social Attitudes: The 21st Report. London: SAGE, pp. 147-165.

Van Assche J, Roets A and Van Hiel A (2017) The mobilizing effect of right-wing ideological climates: Crosslevel interaction effects on different types of outgroup attitudes. Political Psychology 38(5): 757-776.

Verkuyten M, Thijs J and Bekhuis H (2010) Intergroup contact and ingroup reappraisal examining the deprovincialization thesis. Social Psychology Quarterly 73(4): 398-416.

Visintin EP, Green EGT and Sarrasin O (2018) Inclusive normative climates strengthen the relationship between identification with Europe and tolerant immigration attitudes: Evidence from 22 countries. Journal of Cross-Cultural Psychology 49(6): 908-923.

Voci A and Hewstone M (2003) Intergroup contact and prejudice toward immigrants in Italy: The mediational role of anxiety and the moderational role of group salience. Group Processes \& Intergroup Relations 6(1): $37-54$.

Wagner U, Christ O, Pettigrew TF, et al. (2006) Prejudice and minority proportion: Contact instead of threat effects. Social Psychology Quarterly 69(4): 380-390.

Weber H (2015) National and regional proportion of immigrants and perceived threat of immigration: A three-level analysis in Western Europe. International Journal of Comparative Sociology 56(2): 116-140.

Weldon SA (2006) The institutional context of tolerance for ethnic minorities: A comparative, multilevel analysis of Western Europe. American Journal of Political Science 50(2): 331-349.

Wimmer A (2011) A Swiss anomaly? A relational account of national boundary-making. Nations and Nationalism 17(4): 718-737.

Wimmer A (2013) Ethnic Boundary Making: Institutions, Power, Networks. Oxford: Oxford University Press.

Wright M (2011) Diversity and the imagined community: Immigrant diversity and conceptions of national identity. Political Psychology 32(5): 837-862. 


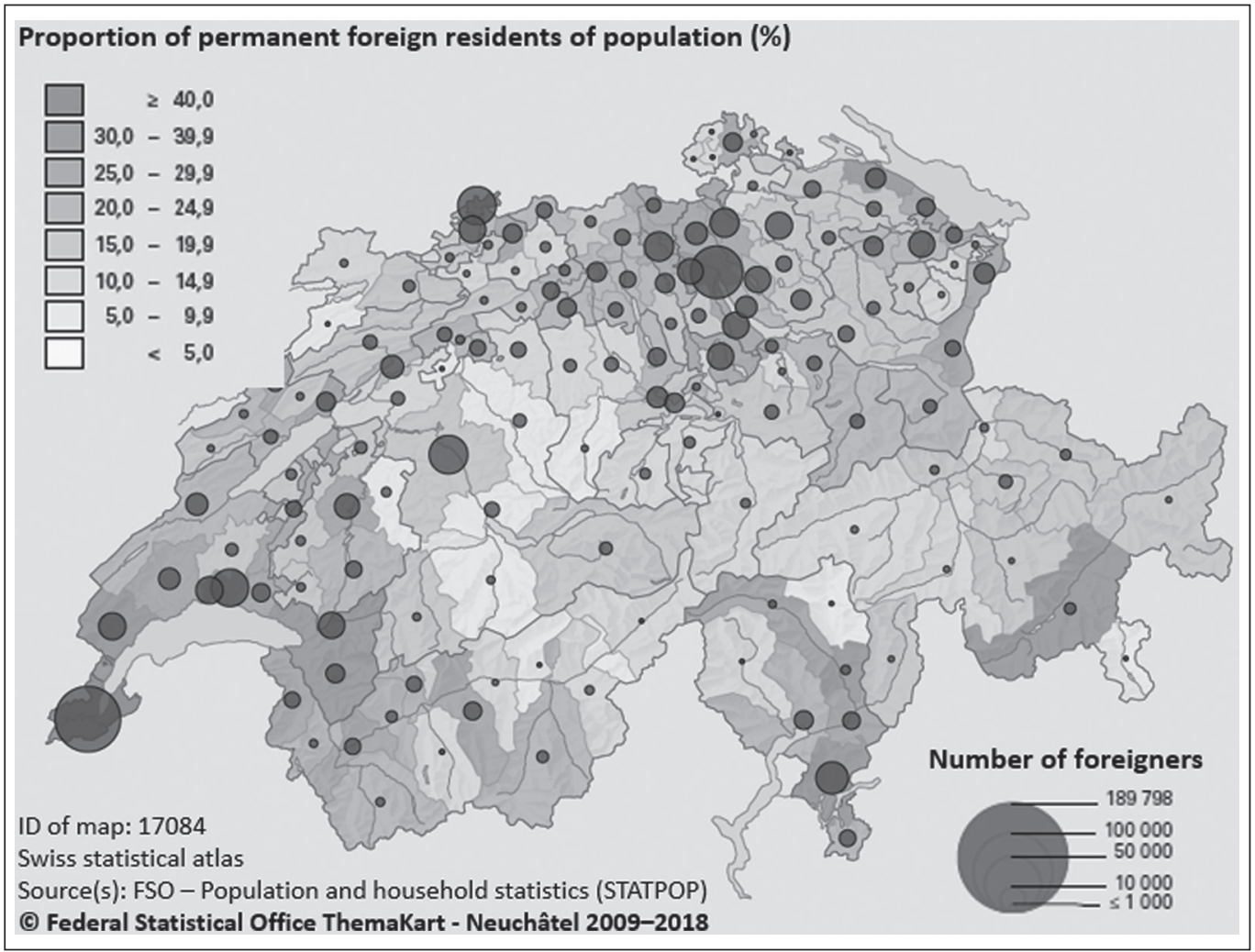

Appendix I. Permanent foreign residents across Swiss districts 2013 (legends translated into English by authors). 
Appendix 2. Unstandardized multilevel regression coefficients and standard errors for individual and contextual predictors of ethnic conception of nationhood.

\begin{tabular}{|c|c|c|c|c|}
\hline & Model 4 & Model $5^{a}$ & Model 6 & Model 7 \\
\hline \multicolumn{5}{|l|}{ Individual-level predictor } \\
\hline Intergroup contact & $-12.30(1.88)^{* * *}$ & $-13.07(1.99)^{* * *}$ & $-12.34(1.87)^{* * *}$ & $-12.43(1.86)^{* * *}$ \\
\hline \multicolumn{5}{|l|}{ District-level predictors } \\
\hline Conservative climate & $0.37(0.37)$ & $0.16(0.38)$ & $0.57(0.42)$ & $0.65(0.45)$ \\
\hline Immigrant ratio & $-0.58(0.36)$ & $-1.06(0.36)^{* *}$ & $-1.02(0.38)^{* *}$ & \\
\hline Immigrant ratio change & $-2.87(2.52)$ & $-1.20(2.4 I)$ & & \\
\hline "Valued" immigrants ratio & & & & $-1.35(0.50)^{* *}$ \\
\hline "Devalued" immigrants ratio & & & & $-1.14(0.89)$ \\
\hline Conserv. clim. $\times$ Immig. ratio & & & $-0.08(0.04)^{*}$ & \\
\hline $\begin{array}{l}\text { Conserv. clim. } \times \text { Immig. ratio } \\
\text { change }\end{array}$ & $-0.55(0.36)$ & & & \\
\hline $\begin{array}{l}\text { Conserv. clim. } \times \text { "Val." } \\
\text { immig. ratio }\end{array}$ & & & & $-0.19(0.07)^{* *}$ \\
\hline $\begin{array}{l}\text { Conserv. clim. } \times \text { “Deval.” } \\
\text { immig. ratio }\end{array}$ & & & & $0.16(0.18)$ \\
\hline \multicolumn{5}{|l|}{ Cross-level interactions } \\
\hline IG contact $\times$ Conserv. clim. & & $-0.05(0.28)$ & & \\
\hline IG contact $\times$ Immig. ratio & & $0.25(0.24)$ & & \\
\hline $\begin{array}{l}\text { IG contact } \times \text { Immig. ratio } \\
\text { change }\end{array}$ & & $-1.20(1.80)$ & & \\
\hline $\begin{array}{l}\% \text { explained variance: district } \\
\text { level }\end{array}$ & $51.66 \%$ & $38.59 \%$ & $56.94 \%$ & $64.18 \%$ \\
\hline
\end{tabular}

All models accounted for sociodemographic control variables.

alntergroup contact was group-mean centered for testing cross-level interaction in Model 5.

${ }^{*} p<05 .{ }^{* * *} p<.01 .{ }^{* * * *} p<.001$. 